\title{
Prevention and intervention for victims of violence in occupational therapy
}

\author{
Wendy Young. B.OT, M.OT (UKZN), CHT (HTCC). https://orcid.org/0000-000 I-9 I I 7-9840 \\ Consultant, Wendy Young Vicki Hofmann Occupational Therapy, Inc. Umhlanga, KwaZulu-Natal, South Africa.
}

South Africa has one of the highest rates of violent crime in the world resulting in a significant public health concern. The adverse effects are not limited to death and physical injury, but also include numerous other issues which are of immediate concern to occupational therapists, such as depression, anxiety and occupational disabilities. These are risk factors for substance abuse, relationship difficulties and unsafe sexual practices. Intergenerational effects occur when children witness or experience violence and a cycle of violence is established. Yet, occupational therapists contributing to the South African Journal of Occupational Therapy, South African Society of Hand Therapists and the 2018 World Federation of Occupational Therapy congress do not appear to have prioritised this topic. Occupational therapists have been called to address the social determinants of health, to rethink their roles, to become activists and to promote justice. This opinion piece serves as a stepping-stone to further encourage South African occupational therapists to consider a turnaround (pivot) and to face the challenge of becoming leaders in the Prevention and Intervention for victims of Violence in Occupational Therapy (PIVOT).

\section{INTRODUCTION}

Violence is a significant public health problem in South Africa. It has been reported that $69 \%(n=75)$ of extensor tendon injuries of the hand in KwaZulu-Natal were the result of violence'. In the South African context, occupational therapists are faced with a homicide rate that is 5.7 times the global average ${ }^{2,3}$. Yet, there are few studies in occupational therapy that focus on violence, its adverse effects, primary or secondary prevention strategies and optimal intervention thereafter.

\section{Violence statistics in South Africa}

South Africa has one of the highest levels of violent crime in the world ${ }^{4,5}$, ranking $5^{\text {th }}$ in 20186 . This is compared to data from I33 countries accounting for $88 \%$ of the world's population ${ }^{4}$. In the 2018/2019 financial year, South African Police Services recorded 21036 homicides within an estimated population of $57700000^{2}$. This equates to 36.4 homicides per 100000 people ${ }^{2,6}$ and an average of 57 murders a day, ${ }^{6}$. While there has been a significant decline in the level of violence since its peak in 1994, when the murder rate was 70 per 100000 , violent crime has been increasing again steadily since $20 \mathrm{I} \mathrm{I}^{5,6}$. It is perhaps more relevant to point out that for every murder, there is an average of 20 to 40 times more victims injured through violence, which indicates that they might need occupational therapy services ${ }^{4,5}$. This is demonstrated in that for the South African clinician rehabilitating clients after injury, approximately $50 \%$ are intentional as opposed to accidental ${ }^{7}$. Occupational therapists working with youth and young adults are likely being frequently exposed to these clients ${ }^{1,8}$ since 12 to 29 -year-olds are most often the victims and perpetrators of violence ${ }^{7,9}$. While there has been increased media attention directed towards reducing gender-based violence in South Africa, it is seldom mentioned that six times more men die from violence than women ${ }^{7}$.

\section{Why should health professionals concern themselves with violence?}

The World Health Organisation declared violence a global health issue in $1997^{10}$ and has called on health professionals worldwide to do scientific research, collect data and collaborate with other disciplines to contribute towards the prevention of, and intervention after, violence ${ }^{4}$. Many sources detail the long-term adverse effects of violence since it not only leads to an untimely death, but also numerous other issues which are of immediate concern to occupational therapists, such as physical disability, depression, anxiety and occupational difficulties ${ }^{4,11}$. These are risk factors for suicide, substance abuse, relationship difficulties and unsafe sexual practices, which in turn, are risk factors for HIV and cardiovascular problems ${ }^{4}$. Intergenerational effects occur when children witness or experience violence in places that are supposed to be safe, such as their homes or schools, and a cycle of violence is established ${ }^{9}$. In addition, therapists who listen to repeated stories of violence are faced with the possibility of experiencing distress, strong emotional reactions, intrusive images or shattering of beliefs, defined as vicarious trauma ${ }^{12}$.

\section{Are occupational therapists in South Africa adequately} addressing violence?

The quantitative data used to formulate this opinion piece were gathered as part of a literature review for a master's thesis on violent hand amputation and replantation in South Africa. Three occupational therapy institutions namely SAJOT, WFOT and SASHT were numerically appraised, over specified time periods, to determine how frequently they had addressed the subject of violence, as indicated by the titles of their articles, presentations, posters and workshops. While the title of an article or presentation is certainly not a comprehensive reflection of the content, it does give some indication as to whether violence might have been discussed or prioritised. Words such as violence, post-traumatic stress disorder 
Table I: Frequency of occupational therapy articles or workshops related to violence as indicated by the title alone***

\begin{tabular}{|l|l|l|l|l|}
\hline Journal/ Society/Congress & Dates reviewed & $\begin{array}{l}\text { Total number of articles or } \\
\text { workshops }\end{array}$ & $\begin{array}{l}\text { Possibly related to violence } \\
\text { as indicated by title alone }\end{array}$ & Violence in title \\
\hline SAJOT & $\begin{array}{l}2010 \text { (Vol 3) to } \\
2020 \text { (Vol 2) }\end{array}$ & $\begin{array}{l}268 \text { published articles appraised } \\
\text { (Title only) }\end{array}$ & $\begin{array}{l}3 / 268=1.1 \% \\
\text { (Aggressive, unrest, gang) }\end{array}$ & $0 / 368=0 \%$ \\
\hline SASHT & $\begin{array}{l}2015 \text { to } 2020 \\
250 \text { emails } \\
\text { screened }\end{array}$ & $\begin{array}{l}40 \text { workshops advertised and } \\
\text { appraised } \\
\text { (Title only) }\end{array}$ & $\begin{array}{l}2 / 40=5 \% \\
\text { (Trauma } \times 2)\end{array}$ & $0 / 40=0 \%$ \\
\hline WFOT & 2018 congress & $\begin{array}{l}665 \text { in total }(586 \text { oral } \\
\text { presentations and } 79 \text { guided } \\
\text { posters) appraised } \\
\text { (Title only) }\end{array}$ & $\begin{array}{l}\text { I2/665 }=1.8 \% \\
\text { (PTSD, wounded soldiers in } \\
\text { Ukraine, forensic psych } \times 7, \\
\text { criminal } \times 2, \text { gangsters) }\end{array}$ & $2 / 665=0.3 \%$ \\
\hline
\end{tabular}

**(This information does not necessarily imply that violence was not covered).

(PTSD), trauma, aggression, unrest, gangs, and criminals were enumerated from the titles.

First, information gleaned from the official SAJOT website revealed that no authors have published an article with the word 'violence' in the title from 2010 to 2020 . Titles that indicated a possible link to violence included words such as 'aggressive' and 'unrest', and this constituted $\mathrm{I} . \mathrm{I} \%$ of the total number of articles published by SAJOT in the past decade. Similarly, SASHT advertised at least 40 workshops* via email from 2015 to 2020 of which $5 \%$ had the word 'trauma' in the title, which could infer topics related to violence were covered. None of those appraised were found to have 'violence' in the title, over the same period. Lastly, the WFOT Congress held in 2018 in Cape Town had two presentations out of a total of 665 with 'violence' in the title, as displayed by the official online programme. One of these presentations considered the victim and the other the perpetrator i.e.: $0.3 \%$ of the presentations at this congress prioritised violence, as indicated by the title alone. Additional titles that had a possible link to violence included words such as 'PTSD' and 'forensic mental health' and this constituted $1.8 \%$ of the total number of presentations and posters.

In my opinion, this demonstrates that South African occupational therapists are either,

- not considering the prevention of violence,

- not exploring how this violence is affecting their clients and themselves,

- not researching the best ways of treating someone injured through violence,

- not prioritising the subject of violence,

- or they are not adequately publishing and sharing this vital information.

\section{Prevention and Intervention for Victims of Violence in Occupational Therapy}

In the most recent issue of SAJOT, occupational therapists are called to address the social determinants of health and to prioritise 'voices from the margins' which among others, include those affected by gender-based violence ${ }^{13}$. Similarly, therapists have been encouraged to rethink their roles, collaborate with leaders in the profession and become not only advocates for the vulnerable, but activists $^{14}$. Occupation-based Community Development (ObCD) $)^{15}$ is an example of a framework that has been designed to guide oc- cupational therapists in the promotion of justice, especially within marginalised communities. This opinion piece serves as a steppingstone to further encourage occupational therapists to collaborate with other health disciplines, community members, religious leaders and policy makers on the issues of violence. Violence should be a topic for post-graduate courses and workshops which may include primary, secondary, and tertiary prevention strategies, PTSD, building resilience, intervening in family, work and school environments affected by violence, recognising, preventing, and dealing with vicarious trauma and more. Examples are a psychosocial therapist presenting at a hand therapy workshop or a community therapist exploring and implementing ObCD and implementing primary prevention stategies ${ }^{15}$. Reflecting on the adverse health effects of violence and the statistics in our country, South African occupational therapists should consider a turnaround (pivot) and face the challenge of becoming leaders in the Prevention and Intervention for victims of Violence in Occupational Therapy (PIVOT).

\section{REFERENCES}

I. Mottay N, Govender P, Mpanza D. The use of the ICAM Splint Programme in Zone IV to VII Extensor Tendon Repairs: Patient outcomes and clinician experiences in a specialised hand unit in SA. South African Journal of Occupational Therapy. 2020;50(2):23-34. https://doi.org/10.17159/2310-3833/2020/vol50no2a4

2. SAPS. South African Police Service Annual Report 2018/2019 | South African Government. Pretoria; 2019. https://www.gov.za/ xh/node/79325I. Accessed March 14, 2020.

3. WHO. Violence Info. Homicide. WHO Global Health Estimates (20I5 Update);; 20I5. https://apps.who.int/violence-info/homicide/. Accessed November 10, 2020.

4. WHO. World Health Organization. Global Status Report on Violence Prevention 2014.; 20I4. https://www.who.int/violence_injury_prevention/violence/status_report/20I4. Accessed March I3, 2020.

5. Loots DP, Saayman G. Medicolegal perspectives of interpersonal violence: A review of first-contact clinical notes. South African Medical Journal. 2019;109(10):792-800. doi: https://doi.org/10.7196/samj.2019.v109il0.1395I

6. Cook N. South Africa: Current Issues, Economy, and U.S, Relations.; 2020. https://crsreports.congress.gov.

7. Matzopoulos R, Prinsloo M, Pillay-Van Wyk V, et al. Injury-related mortality in South Africa: A retrospective descriptive study of postmortem investigations. Bulletin of the World Health Organisation.

*Emails reviewed may not have been an exhaustive list. 
8. Motimele MR, Ramugondo EL. Violence and Healing: Exploring the Power of Collective Occupations. International Journal of Criminology and Sociology. 2014;3:388-40I.

https://doi.org/10.6000/1929-4409.2014.03.33

9. Burton P. Someone Stole My Smile: An Exploration into the Causes of Youth Violence in South Africa. (Burton P, ed.).; 2007.

https://catalog.ihsn.org/index.php/citations/I 1636. Accessed November 28, 2020.

10. Hoffman JS. World Report on Violence and Health.: Edited by E G Krug, L L Dahlberg, J A Mercy, A Zwi, R Lozano. (p 340;) Geneva: World Health Organization, 2002. ISBN 92-4-I5456I-5. Inj Prev. 2003;9(I):93-93 http://dx.doi.org//0.1 I36/ip.9.1.93

II. Hughes G. Reducing violent injury. Emergency Medicine Journal. 20I I;28(I0):824. http://dx.doi.org/I0. I I36/emermed-20 I I-200545

12. Cohen $\mathrm{K}$, Collens $\mathrm{P}$. The impact of trauma work on trauma workers: A metasynthesis on vicarious trauma and vicarious posttraumatic growth. Psychological Trauma: Theory, Research, Practice, and Policy. 2013;5(6):570-580. https://doi.org//0.1037/a0030388

13. Williams E, de Wit PA. Guest Editorial. South African Journal of Occupational Therapy. 2020;50(2):2-3. Accessed November 22, 2020. http://dx.doi.org/10.17/59/23/0-3833/2020/vol50no2al

14. Joubert R. Occupational catastrophe! The digital revolution, global warming, unrest and pandemics: are we prepared? South African Journal of Occupational Therapy. 2020;50(2):77-83. Accessed November 22, 2020.

http://dx.doi.org//0.17159/2310-3833/2020/vol50no2al0

15. Galvaan R, Peters L. Occupation Based Community Development Framework. Open Education Resource: University of Cape Town. 20I4. https://vula.uct.ac.za/access/content/group/9c29ba04-blee49b9-8c85-9a468b556ce2/OBCDF/index.html. Published 2014. Accessed May 30, 2021. 